\title{
Imperious Freedom: The Tangled Narratives of Anti-Human Trafficking Discourse
}

Kari J. Winter and David R. Castillo

$[\mathrm{H}]$ istory reveals itself only through the production of specific narratives.

-Michel-Rolph Trouillot, Silencing the Past

At the dawn of the twenty-first century President George W. Bush channeled millions of dollars into a crusade against modern-day slavery or "human trafficking" at the same time that he launched an invasion of Iraq, a ferociously unpopular war that threatened to bankrupt America's moral capital around the globe. Casting the United States as a nation of heroic freedom fighters engaged in a global struggle against slavery, the Bush Administration promulgated a fable of moral clarity that staked a claim to American citizens' humanitarian impulses while elaborating justifications for US imperialism. Bush was able to capitalize on sentiments stirred by anti-trafficking literature, most notably Kevin Bales's Disposable People: New Slavery in the Global Economy (1999), which made the shocking assertion that 27 million people are enslaved worldwide. Since then scholars, journalists, politicians, and NGOs have shown that human beings are held in bondage and forced to work without wages in every nation-state and every major city on earth, from Pakistan to Brazil, to Thailand to Paris, to Main Street, USA. In 2011 the U.S. Department of Homeland Security broadcast television ads in Mexico, Central America, and the southern United States warning people of the dangers of human trafficking. ${ }^{1}$ Activists in Brazil plastered their country with billboards and commercials urging an end to modern slavery; CNN launched a worldwide "Freedom Project" to end "modern-day slavery" and countless other efforts were undertaken on behalf of what has been widely touted as the greatest moral issue of our age.

While the horror of slavery is inarguable, the goals of anti-trafficking agitation are often murky. ${ }^{2}$ Unlike eighteenth and nineteenth-century abolitionists who aimed to end the licit and illicit transatlantic transport of enslaved Africans and to abolish the legal institutions of slavery within nation-states, twenty-first century abolitionists seek to end practices of enslavement that are, in most cases, illegal, subterranean, and hard to locate. The most popular methods of contemporary abolitionists, which are clearer than their goals, include increasing police surveillance, tightening borders, growing prisons, and conducting "rescue missions." Like many "moral" issues, human trafficking is a porous concept that expands and contracts easily to suit a range of purposes. In this essay we analyze the standard narrative structures through which bondage and freedom are imagined and represented in contemporary British and American political

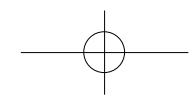


discourse. We focus on the work of three of the most popular and influential antislavery activists in the world today: David Batstone, a professor of ethics at the University of San Francisco who makes regular appearances as "America's ethics guru" in USA Today's Weekend Edition; Nicholas Kristof, a Pulitzer-Prizewinning investigative journalist and New York Times columnist; and Kevin Bales, the President of Free the Slaves who is acclaimed as a latter-day William Wilberforce. All three writers exhibit deep humanitarian compassion, and their political and ideological alignments cover a broad spectrum that cannot be pigeonholed. The goal of this essay is to illuminate how power works through narrative structures in ways that writers often do not intend or understand. As the Haitian historian Michel-Rolph Trouillot has observed, "Power is constitutive of the story."3

In 2007 David Batstone opened his book, Not for Sale: The Return of the Global Slave Trade_-and How We Can Fight It, by placing the Bush Administration in the position of the world's moral arbiter. "Defeating human trafficking is a great moral calling of our time," declares Condoleezza Rice on the back cover and in an epigraph. Batstone asserts:

Just how prominent a global crisis the slave trade has become was apparent when President George W. Bush took the podium before the United Nations General Assembly in September 2003. As expected, the president first addressed international concerns over the U.S. intervention in Iraq. As he neared the end of his speech, Bush shifted his attention to "another humanitarian crisis" of global proportions. "Each year 800,000 to 900,000 human beings are bought, sold, or forced across the world's borders," he said. "The trade in human beings for any purpose must not be allowed to thrive in our time." Bush went on to underscore how the slave trade targets vulnerable women and children and fuels a thriving organized crime syndicate that threatens global security. 4

Batstone then quotes Barry Tang, "an Immigration and Enforcement attache with the U.S. Department of Homeland Security," who says the profits from human trafficking are "on a path to overtake drugs and arms trafficking." 5 Former congressman John Miller, appointed by Bush to head his new Office to Monitor and Combat Trafficking in Persons, adopts Condoleezza Rice's sound 
bite. Human trafficking, he says, "is one of the great moral struggles of our day. We need to bring the same passion and commitment to this struggle that abolitionists of this country brought to the struggle against slavery based upon color 160 years ago." 6

The timing of the new abolitionism-its popular emergence during the Bush Administration-is significant. Since the late eighteenth century when the British abolitionist movement gained power in London, which had been for two centuries the dominant European player in the transatlantic slave trade, abolition has been connected not only to political struggles within nation-states but also to ways that various empires and nation-states have competed with each other for moral capital to bolster their image in the world. Hence the Bush Adminstration's decision to link the launching of its anti-human trafficking campaign with its invasion of Iraq. Righteous indignation on behalf of victims and celebration of heroes for their valiant struggle against evil is the twenty-first century abolition's overarching tone. Batstone explicitly presents us with "a heroic ensemble of abolitionists who simply refuse to relent. I felt like I had gone back in time and had the great privilege of sharing a meal with a Harriet Tubman or a William Wilberforce or a Frederick Douglass." 8 He exhorts readers to discover what they can do to "arrest" the global slave trade by following his lead and the example of others, most of whom are evangelical crusaders. "We" are invited to imagine ourselves not only as his story's hero but also as central actors in history. "All of us wonder how we would have acted in the epic struggles of human history. Would we have stood up and been counted among the courageous and the just?"9

David Batstone explicitly asks his readers: Wouldn't you want to imagine yourself as a valiant resistor who hid Jews from Nazis, protected fugitive slaves from slave catchers, or missionized Indians in the New World? The last example is worth quoting verbatim. He asks, "what if we were in the company of Jesuits who established a mission in the New World in 1624? The Spanish slave traders warn us to dismantle our mission where the natives work and keep their tribal structure intact. 'We control this territory,' they would have said, 'and you are undermining our lucrative trade in natives. End the missions now'."10 In actuality Jesuits were central actors in the process that the United Nations, since 1948, has called cultural genocide, but Batstone offers an imperialist fantasy that whitewashes rather than engages history. Postcolonial critics such as Edward Said, Anibal Quijano, and Walter Mignolo have shown that the "coloniality of power" (to use Quijano's phrase) often hides under the cloak of self-serving notions of universality, human progress, and moral balance. ${ }^{11}$ Their fundamental insights into the structure of colonial discourse illuminate the ideological core of many of Batstone's narratives. By positioning readers as universal liberators 
and protectors, he situates them on the side of modern imperialism.

Most twenty-first century antislavery discourse presents its argument in the form of simplistic vignettes in which heart-of-gold heroes rescue innocent victims of violent predators from bondage. The reader is constructed as unquestionably good and just, while the "others" who inhabit Asia, Africa, and South America are either abject victims or one-dimensional villains. Focusing on victims who need to be saved, "we" evade questions of historical and personal complicity and complexity. Individual stories are foregrounded, while systemic analysis is largely foreclosed. In their celebrated book, Half the Sky: Turning Oppression into Opportunity for Women Worldwide, Nicholas D. Kristof and Sheryl WuDunn advance the heroic rescuer model explicitly:

The tools to crush modern slavery exist, but the political will is lacking. That must be the starting point for any abolitionist movement. We're not arguing that Westerners should take up this cause because it's the fault of the West; Western men do not play a central role in prostitution in most poor countries... So this is not a case where we in the West have a responsibility to lead because we're the source of the problem. Rather, we single out the West because, even though we're peripheral to slavery, our action is necessary to overcome a horrific evil. 12

Although some chapters in their book offer careful, multifaceted research into important aspects of non-Western women's oppression, their ahistorical approach whitewashes connections between the poverty that haunts much of the world today and five hundred years of European-dominated slavery, colonialism, and genocide.

One of Batstone's moral exemplars is the International Justice Mission (IJM), which he describes in cartoonish language as "a fearless team of criminal investigators and lawyers [that] works with local law enforcement agencies to rescue slaves from dire situations around the world." 13 IJM is an evangelical Christian organization that has conducted countless brothel raids in India, Cambodia, the Philippines and Thailand to "rescue slaves." IJM's founder, Gary Haugen, encapsulates his heroic self-image in his book title, Terrify No More:

Young Girls Held Captive and the Daring Undercover Operation to Win Their Freedom. ${ }^{14}$ Granted more than four million dollars by the Bush Administration to fight trafficking and prostitution, IJM raises funds and recruits employees by recounting horrific stories of sexual victimization. In 2009 the American left-leaning maga- 
zine The Nation sent a free-lance writer, Noy Thrupkaew, to Asia to investigate the effectiveness of IJM's strategies. Thrupkaew observed that IJM positions itself on the side of law-and-order, collaborating with both the U.S. government and local police even in contexts where there is strong evidence that the police themselves permit or mastermind trafficking and are systematically vicious in their treatment of prostitutes. Many of the "liberated" women and girls have protested that they were arrested, not "rescued." Inattentive to local histories, cultures, and institutions, IJM raids brothels in city after city and country after country, reenacting its fantasy of rescuing helpless victims while often disrupting and undermining the work of local NGOs and international aid organizations. During and after the raids the girls and women sometimes find themselves robbed of all possessions, jailed, subjected to public scrutiny, threatened with deportation, and re-trafficked back to sex work with an even larger burden of debt than before the "rescue." 15 Kristof and WuDunn described a brothel raid conducted by local police in India that "was a catastrophe. Overnight the brothels in that area were closed, with no provision for the girls working there; the prostitutes were so stigmatized that there was no place they could go and no way for them to earn money."16 Many of the "liberated" women committed suicide. Nonetheless, instead of addressing labor laws, migration laws, racism, police violence, or other systemic issues, IJM clings to its "ardent sense of mission, its moral clarity about justice work."17

Kristof has spent decades researching slavery, especially sex trafficking, and his countless New York Times editorials on the topic express passionate anger at the prevalence of vicious exploitation as well as frustration with the West's widespread apathy. Alongside his deep compassion, hard work, and sometimes keen insights, runs an equally deep strain of brash imperialism and pro-capitalist cheerleading. In a New York Times Book Review essay, "How Can We Help?" he ponders the problem that "doing good is harder than it looks" and evaluates the strengths and weaknesses of various humanitarian efforts while making it clear that structural solutions are not worth entertaining. "In the 1960s," he concludes, "there were grand intellectual debates about whether capitalism was heroic or evil; today we simply worry about how to make it work." 18 Capitalism, for Kristof, is the solution, not part of the problem. He opens a 2009 column, "Striking the Brothels' Bottom Line" with the assertion: "In trying to figure out how we can defeat sex trafficking, a starting point is to think like a brothel owner."19 In 2004 he purchased two teenagers and returned them "to their villages and worked with a local aid group to help them start small businesses." One liberated girl "did wonderfully, learning hairdressing and marrying a terrific man," while the other girl "was addicted to methamphetamine and fled back to the brothel world to feed her craving." 20 Kristof's experiences illustrate the diffi- 
culty of "freeing" individual slaves when oppressive systems remain intact.

Buying slaves in order to free them ends up strengthening the market. Many North American churches have collected money to go overseas and free slaves by buying their freedom, which not only increases the profitability of slave-trading but also encourages profiteers to create a scam market that caters to the rescue fantasies of wealthy Westerners. International human rights organizations such as the United Nations Children's Fund (UNICEF) and Human Rights Watch have denounced slave redemption practices as absolutely intolerable because they tend to exacerbate rather than alleviate the problems of human trafficking. Prominent scholars recently have analyzed the problematics of slave redemption in an essay collection edited by Kwame Anthony Appiah and Martin Bunzl, Buying Freedom: The Ethics and Economies of Slave Redemption (2007). ${ }^{21}$

Like Kristof, Batstone has spent years investigating brothels. Although he notes that "[s] exual tourism clearly feeds the beast of sexual slavery," he departs from his usual tendency to imagine all prostitution as a form of slavery in order to assure his readers that there are significant differences between "Western sex tourists" and "Japanese and Chinese" johns as well as "local" Asian men in general. ${ }^{22}$ After providing prolific details about the ways in which Asian men's use of sex slaves and prostitution "has become embedded in many social rituals," he informs his implicitly white, Western reader:

Sexual tourism could end tomorrow, but it would make only a modest change in the flow of sexual slavery in Southeast Asia. In fact, at the sights frequented by sexual tourists, a minority of women who work are enslaved. By and large, bar owners consider it too risky to present enslaved women to foreign men. ... Enslaved women, on the other hand, typically are found in brothels that cater to local men. 23

Kristof and WuDunn replicate Batstone's distinction between Western and Asian johns in a way that explicitly exempts "the West" from responsibility for the horrors of sex trafficking. They admit that:

American and European sex tourists are part of the problem in Thailand, the Philippines, Sri Lanka, and Belize, but they are still only a small percentage of the johns. The vast majority are local men. Moreover, Western men usually go with girls who are more or less voluntary prostitutes, because they want to take the girls 
back to their hotel rooms, while forced

prostitutes are not normally allowed out of

the brothels. 24

However, drawing a clear line between coercion and choice becomes impossible as soon as one moves away from simplistic plot lines and listens to the complex stories that people tell about their lives. Kristof and WuDunn employ at least two very different narrative voices in their book; one voice acknowledges complications, while the other refuses to know what they know. For instance, a few pages after drawing the above distinction between the enslaved prostitutes used by "local" men and the voluntary prostitutes used by Western men, they narrate the stories of the two teenagers mentioned above--Srey Neth and Srey Momm-whom Kristof purchased in order to liberate. Their stories "underscore that many prostitutes are neither acting freely nor enslaved, but living in a world etched in ambiguities somewhere between those two extremes." 25 Julia O'Connell Davidson puts the matter in a clearer light:

Whether we are talking about sex work or any other form of labour, the line between coercion and consent is not and never has been clear-cut. In the absence of alternative opportunities, or where the inducements are great enough, people can and do volunteer to enter contracts that may harm them or that they would not otherwise choose to enter. $^{26}$

Most human beings desire, consciously or unconsciously, to express truths about their lives because, as Mikhail Bahktin observes:

I achieve self-consciousness, I become myself only by revealing myself to another, through another and with another's help. The most important acts, constitutive of self-consciousness, are determined by their relation to another consciousness (a "thou"). . . The very being of man (both internal and external) is a profound communica -

tion. To be means to communicate. ${ }^{27}$

Perhaps the most indelible violence of enslavement and rape is the traumatizing message of predators whose form of communication stakes a claim to the victim's self-consciousness by inculcating the message that they are not fully human, and they have no socially recognized rights; they are merely body parts from which the predators are entitled to take pleasure and profit. This message is personal, but it is not merely personal. It is undergirded by enormous ideological and 
institutional force. One of the reasons systems of oppression are so intransigent and "freedom" is so hard to realize is that relations of oppression largely shape the self-consciousness of the oppressed unless their consciousness is transformed by other forms of profound communication that is open to wrestling with whatever realities of trauma, shame, ideology, addiction, dependency, education, and ambition, among other things, shape each individual's interior life. Storming a brothel and declaring prostitutes to be free is a monologic act, not a dialogue.

The material and spiritual conditions of "freedom" are intertwined with processes of domination and discipline in intricate, slippery, and often-paradoxical ways. Historically, the very notion of freedom emerged in a close dialectical relationship with slavery and the oppression of women, as Harvard sociologist Orlando Patterson has shown.

Freedom began its long journey in the

Western consciousness as a woman's value. It was women who first lived in terror of enslavement, and hence it was women who first came to value its absence, both those who were never captured but lived in dread of it and, even more, those who were captured and lived in hope of being redeemed or, at the very least, being released from their social death and placed among their captors in that new condition which existentially their whole being had come to yearn for. 28

Freedom, Patterson shows, holds personal, sovereignal, and civic meanings. Personal freedom involves the ability to pursue one's desires without coercion or restraint "within the limits of other persons' desire to do the same."29 Sovereignal freedom is "the power to act as one pleases, regardless of the wishes of others." 30 Civic freedom is:

the capacity of adult members of a community to participate in its life and governance. A person feels free, in this sense, to the degree that he or she belongs to the community of birth [or, we might add, adoption], has a recognized place in it, and is involved in some way in the way it is governed. The existence of civic freedom implies a political community of some sort, with clearly defined rights and obligations for every citizen. 31 
In many cases, "rescue” operations stage the rescuers' sovereignal freedom their power to act, to define, and to enforce. The "rescuer" does not participate in a conversation informed by the voices, priorities, and dreams of the "rescued," nor do the "rescued" find themselves suddenly in possession of personal or civic freedom.

Anthony M. DeStefano, who has reported many stories about human trafficking for Newsday and The Wall Street Journal, acknowledges the shortcomings of journalistic interventions in his richly informative book, The War on

Human Trafficking: U. S. Policy Assessed. 32 Because "human interest" stories tend to be formulaic, easy to write, and popular, journalists, whose profession is based on grabbing readers' attention in short pieces written against pressing deadlines, tend to produce sensationalized accounts of sexual exploitation that are short on research, context, and fact-checking. Recounting the development of American anti-trafficking policies in the context of the Clinton-Bush transition, the 9/11 attacks, and Bush's War on Terror, DeStefano points out that even progressive policy-makers like Paul Wellstone and Diane Feinstein tended to obsess about details of sexual rather than labor exploitation in their anti-trafficking speeches. The Bush Administration in turn used anti-trafficking laws to launch a broad attack on prostitution. The narrative vignettes of abolitionist discourse mimic the bare-bones, reductive caricatures of pornography with endless repetitions of the phrases and images of "sex slave," "rape," "predators," "virgin," and "innocent victim." Kristof and WuDunn rely heavily on this narrative device even after hearing explicit objections from the women whose stories they tell. For instance, they provide a detailed narration of the gang-rape and public humiliation of a Pakistani teenager, Mukhtar Mai, who later became a world-renowned educator of girls. Two pages later they note that when visiting the United States Mukhtar found media interviews "tiresome, partly because reporters weren't interested in her school but only in the rape. That's all they asked: So what was it like being gang-raped? Mukhtar had a disastrous live interview on the CBS morning news in which she was asked about it. Mukhtar indignantly replied: I don't really want to talk about that."33 Kristof and WuDunn decide to publish the story that Mukhtar did not want to talk about and also to publish her critique, as if she were objecting to other journalists but not to their own proclivities.

In Erotic Innocence: The Culture of Child Molesting (1998) James R. Kincaid documents American culture's current obsession with gothic stories of children's sexual victimization. He notes that the stories are constructed in such a way that "we," the people who write and consume the stories, "need never acknowledge our own part in creating this erotic spectacle."34 Similarly, in her carefully researched and analyzed book, Children in the Global Sex Trade (2005), Julia O'Connell Davidson points out that the cultural taste for stories of children's sexual violation reveals more about the audience than it does about the sources 
of children's suffering. The popular press tends to recount endless stories of sexual predation while glossing over other sources of suffering. O'Connell Davidson asks readers to

consider the fact that over five million of the world's children per year "die from illnesses and other conditions caused by the environments in which they live, learn and play" (WHO, 2003). Diarrhea, caused by lack of access to a clean water supply, is thought to account for 12 percent of deaths of children aged under 5 in developing countries; malaria kills approximately one million children per year, mostly in subSaharan Africa (WHO, 2003). Children in at least sixty-eight countries are at risk from land-mines contaminating the land they live on-Angola, for instance, "has an estimated 10 million land-mines and an amputee population of 70,000 , of whom 8,000 are children (UNICEF, 2003)."35

Cultural analysts have long noted that the social constructs of slavery and freedom are interdependent. The effectiveness of abolition in the twenty-first century is diminished not only by an inadequate understanding of the local and geopolitical forces of oppression but also by a willfully naïve, heavily ideological understanding of freedom. Kristof, for instance, proposes that the problem of human trafficking would be diminished if powerful countries would open more sweatshops in poor countries. Fragile democracies like Liberia need "factories to employ people, build skills and pay salaries and taxes. Americans are horrified by sweatshops, but nothing would help Liberia more than if China moved some of its sweatshops there, so that Liberians could make sandals and T-shirts."36 Misery is tolerable as long as it isn't really slavery (a synonym for what is intolerable) or prostitution (another synonym for what is intolerable). Homelessness, poverty, unemployment, starvation, lack of access to health care, and lack of access to education are represented as unfortunate problems but not as conditions that are incompatible with freedom.

Kevin Bales, who retired from his professorship in sociology at Roehampton University in London to work full-time as President of Free the Slaves, an abolitionist organization in Washington D.C. that is connected to Britain's Anti-Slavery International, has worked indefatigably to bring an end to slavery. An extremely popular writer and speaker, he has been showered with international awards; a documentary film based on his work, Slavery: A Global 
Investigation, won a Peabody award and two Emmys, and Disposable People, which has been translated into ten languages, was nominated for a Pulitzer Prize. Among Bales' many distressing tales in Disposable People, one story is particularly haunting.

On more than ten occasions I woke early in the morning to find the corpse of a young girl floating in the water by the barge. Nobody bothered to bury the girls. They just threw their bodies in the river to be eaten by the fish.

This was the fate of young girls enslaved as prostitutes in the gold min ing towns of the Amazon, explained Antonia Pinto, who worked there as a cook and a procurer. While the developed world bemoans the destruction of the rain forests, few people realize that slave labor is used to destroy them. Men are lured to the region by promises of rich es in gold dust, and girls as young as eleven are offered jobs in the offices and restaurant that serve the mines. When they arrive in the remote mining areas, the men are locked up and forced to work in the mines; the girls are beaten, raped, and put to work as prostitutes. Their "recruitment agents" are paid a small amount for each body, perhaps \$150. The "recruits" have become slaves—not through legal ownership, but through the final authority of violence. The local police act as enforcers to control the slaves. As one young woman explained, "Here the brothel owners send the police to beat us . . if we flee they go after us, if they find us they kill us, or if they don't kill us they beat us all the way back to the brothel." The brothels are incredibly lucrative. The girl who "cost" \$150 can be sold for sex up to ten times a night and bring in $\$ 10,000$ per month. The only expenses are payments to the police and a pittance for food. If a girl is a troublemaker, runs away, or gets sick, she is easy to get rid of and replace. Antonia Pinto described what happened to an eleven-year-old girl when she refused to have sex with a miner: "After decapitating her with his machete, the miner drove around in his speedboat, showing off her head to the other miners, who clapped and shouted their approval."37

This passage encapsulates many of the profound truths and structural falsifications that, in our view, simultaneously propel and cripple local, national, and geopolitical efforts to end slavery in the twenty-first century. Bales represents slavery as an exception to rather than part and parcel of modern global capitalism. He casts slavery as a pre-modern relic that rears its ugly head in remote exotic places, much to the surprise of citizens of the "developed world." "We" bemoan the destruction of the rain forests, while money-grubbing slave traders (procurers) and slaveholders in the Amazon will stop at nothing in their greedy exploitation of the Amazon's resources. He tends to ignore the ways in which 
individuals, corporations, and governments in the developed as well as in the developing world are central players in and financial beneficiaries of both slavery and environmental destruction. Reducing human life to a fungible commodity is not a quaint relic of olden days but rather is the paradigm of social relations under globalization. Capitalism imagines people, animals, and the earth as commodities available for non-reciprocal profit, consumption, pleasure, and disposal. Bales's description of slavery neglects several key questions. How is slavery, "which focuses on big profits and cheap lives," distinct from capitalism or other economic systems based on domination and exploitation? How is the "new" slavery connected to local, regional, national, and transnational mechanisms of surveillance, policing, militarism, and terror? Meredeth Turshen notes that Bales defines slavery in ways that are so sweeping that "most married women on the Indian subcontinent could be counted as new slaves" but his definition precludes consideration of "prison labor in the United States and China, or women's labor under some marriage contracts, or even forced labor under European colonialism." 38 It is worth noting that the official global consensus that slavery is evil emerged in the 1940s when the ideologies of communism and capitalism were struggling for the world's hearts and minds. People of all political persuasions could agree that "slavery" was wrong at the same time that they were violently divided about how to deal with poverty and economic injustice. Because it has become a truth universally acknowledged that "slavery" is evil, Bales assures the developed world that "we" can eradicate it. He even supplies a price tag-we can prove our compassion and buy a clean conscience by expending (merely) several billion dollars. Once we have ended slavery, the majority of the planet can look forward to a life of what Bales calls "tolerable misery."

The structure of Bales's narrative moves predictably from slavery to prostitution to eroticized violence. This plot is continuously reproduced in current global discourse surrounding slavery and human trafficking. The standard drama feature three stock characters — an abject victim, a base trafficker, and a heroic rescuer-in standardized plots that move from innocent simplicity to eroticized victimization to happy salvation. Often accompanied by visual images of abjection, the reductive narratives encourage readers to view victims as innocent dupes, traffickers as cartoonish evil-doers, and the readers themselves as potential heroes who can help to rescue the victims by supporting laws and policies that are on the side of surveillance, policing, militarism, and state power. The drama usually gives only glancing attention to the lives of victims before they were trafficked or to the historical conditions that made them vulnerable to enslavement. Nor are the life stories and world-views of traffickers, johns, and capitalists who exploit enslaved labor illuminated in the standard narrative. Sensationalism discourages, disables, and even disallows insight into the local, national, and geopolitical forces that create the particular states of oppression in 
which human beings are trapped.

Recent analyses of antislavery discourse by Saidiya Hartman and Marcus Woods delineate ways in which abolitionist discourse often reproduces the power relations that it purports to critique by inviting the reader to imagine himself as a heroic rescuer and at the same time "to sit back and enjoy the spectacle of imagined white [or masculine or First World] domination."39 Bales's image of a man holding up a girl's decapitated head while other men leer and applaud replicates a set of images of girls' and women's severed body parts that is iconic in violent pornography. Verbal and visual images of violation and suffering can work to trap people in their moments of greatest pain. These images slide between functioning as tragic spectacles that traumatize and terrorize viewers and triumphalistic souvenirs that re-enact and reinforce the energy of domination. Invited to gaze at the decapitated girl or at victims of countless other atrocities, we position ourselves in the space of the torturer, the photographer, those who count and account for things. Saidiya Hartman observes that slaveholders valued spectacles of power as tools for terrorizing the oppressed and as sites for their own pleasure and self-aggrandizement. "The exercise of power was inseparable from its display because domination depended upon demonstrations of the slaveholder's dominion and the captive's abasement. The owner's display of mastery was just as important as the legal title to slave property. In other words, representing power was essential to reproducing domination." 40 Slavery and gender are not the same systems, but they are intimately intertwined. Their entanglement needs to be addressed explicitly, not collapsed into the category "sexual slavery." Close analysis of Bales's story, for instance, leads us to consider questions of trauma, memory, and narrative. If Antonia Pinto, Bales's informant, worked in a mining camp as a cook for enslavers and slaves and as a procurer of girls for prostitution, her position as narrator needs to be read carefully and critically. How was her ability to observe, to remember, to care, and to narrate affected by experiencing, witnessing and participating in horrific violence? How did she survive? What meanings was she able to find in life or in concepts like truth when spectacles of violence and casual murder constantly assaulted her consciousness? After witnessing the phenomenon of human beings being socially constructed as nameless and disposable, after confronting a reality in which friends and family had no power to intervene or protest when their loved ones were raped, tormented, and killed with impunity, how did Pinto imagine and construct the audience of her tales? We are not arguing that Pinto's stories should be dismissed; rather, they need to be listened to deeply, attentively, and analytically rather than simply being taken and reproduced at face value. While Bales, Batstone, and Kristof usually present the world as a binary struggle between good guys (or girls) and bad guys, a more adequate investigation, narration and analysis of each story would reveal that power and resistance are multi- 
faceted and unstable. Pinto, for instance, occupies at least three roles: victim, procurer, and witness. The men that Bales portrays as innocents duped into slavery in one paragraph are transformed without comment in the next paragraph into vicious johns who rape, mutilate and murder girls. Sex trafficking emerges from local and global cultures that imagine sex as a commodity that is simultaneously desirable and disgusting and treat the providers of sex as social outcasts who are alluring but fundamentally repugnant, debased, filthy, vile and subhuman. Interviewing johns and analyzing their stories led Julia O'Connell Davidson to the insight that dominant constructions of masculinity socialize boys "into the belief that their gender makes them only half human, for they are expected to relinquish the need for care and the capacity to give care. This, it seems to me, is both a brutal and a futile act, and that brutality and futility is reproduced in prostitute use."41 In relation to sexuality, then, neither males nor females are granted full humanity, but the patriarchal, militaristic world order grants men the power, permission, and resources to intimidate, coerce, and exploit women sexually, emotionally, and economically, especially women who are poor and racialized.

Several critics have expressed concern about Bales's use of sensationalistic language to articulate analyses that are sometimes "disconcertingly glib and superficial." 42 Meredith Turshen, for instance, notes his proclivity to blame "government corruption" (in non-Western countries) for poverty and labor exploitation while ignoring "the terms under which international financial institutions have spread capitalism to the third world." 43 She warns that the problem with flawed analysis is that it leads to inadequate solutions. Bales' proposaladopt and enforce laws to punish conspiracy to enslave or to profit from slavery-does nothing to change the structures that oppress the poor. The institutions of the new slavery cannot be outlawed; the structures of capitalism must be transformed if slaves are to be freed in the $21^{\text {st }}$ century. 44

Bales himself has confessed that his lack of adequate research and analysis has sometimes led to disaster. In 2007 he placed a section entitled "I PAVE THE ROAD TO HELL" in the center of his book, Ending Slavery: How We Free Today's Slaves, in which he describes how he and fellow activist John Montagu traveled to Nepal with "the best of intentions" in January 2000, determined to use international pressure to persuade Nepal's government to ban slavery. From 1846 to 1948 Nepal was ruled by a brutal dictatorship backed by British colonial might, but Bales did not doubt his capacity as a British intellectual to place benighted Nepal on the path to freedom. In a whirlwind visit lasting "a little over a week," he helped to set in motion a series of local and international efforts that fulfilled his dream. 45 On July 17 Nepal's king "ordered, by royal edict, that debt-bondage slavery was abolished." 46 Bales confesses that he was filled with "joy and hubris. ... The idea that my work might have been a 
small part of this emancipation thrilled me. ... In my mind's eye, slaves were stepping into the golden light of freedom." 47 To his horror, Bales discovered that the royal edict had devastating consequences.

Emancipation and eviction arrived together, and while happy to be free, the [former slaves] were suddenly homeless, jobless, and hungry. . . .

Some forty thousand people were freed in the five western districts, and most were turned out of their homes. Suddenly the roads were filled with families seeking food and shelter . . . . By early September there were thirty-seven refugee camps in the districts of Kanachanpur and Kailali alone. 48

People began starving to death, and when monsoons came in the autumn "disease broke out, and people, children in particular, began to die of pneumonia, dysentery, malaria, and encephalitis." ${ }^{49}$ As of 2007 two-thirds of the freed families had not received any help, and one-third were still living in refugee camps, leading Bales to lament, "No one knows exactly how many people have died in the refugee camps, but the truth I have to bear is that some died because I pushed too hard and thought too little." 50

In highlighting some of the strengths, dangers and oversights in the most visible, mainstream forms of contemporary abolitionist storytelling, our goal is to encourage the development of more adequate forms of narration that strengthen the local and international struggles for women's rights and for economic justice that are undertaken by hundreds of thousands of scholars, journalists, filmmakers, creative writers, political activists, NGOs and ordinary people every day. Writers of all political persuasions sometimes adopt populist narrative techniques that do a disservice to historical and psychological complexities. Kristof and WuDunn offer an explicit explanation for their choice to focus on personal vignettes. "Frankly, we hesitate to pile on the data, since even when numbers are persuasive, they are not galvanizing. A growing collection of psychological studies show that statistics have a dulling effect, while it is individual stories that move people to act." 51 It is not surprising that many readers are drawn to emotionally riveting but simplistic stories that offer them heroic selfimages. Despite the enormous popularity of such stories, however, there is an expansive body of both popular and academic work that addresses human trafficking in ways that are carefully researched, innovative, and insightful. For example, Ishmael Beah's unforgettable narration of his brutal coercion into childhood military service, A Long Way Gone: Memoirs of a Boy Soldier (2007), shows how important and difficult it is for people to tell their own stories-and how crucial self-narration is to the process of liberation. ${ }^{52}$ His experiences also demonstrate the fluidity of the lines between trafficker and trafficked; traumatized boys who are forced to commit atrocities often grow into drug- and alcohol-addicted men 
who procure the next generation of boys for vicious military service, just as girls who are forced into prostitution often, if they survive long enough, grow into women who help to procure and brutalize the next generation. Major scholars such as Dominick LaCapra have illuminated interconnections between contemporary trafficking in humans and trafficking in animals. ${ }^{53}$ Michele Goodwin and other scholars of legal and medical ethics have exposed the long, racist history of trafficking in body parts. ${ }^{54}$ Rebecca Skloot also has attracted a wide popular audience with her powerful narration of the scientific, racial, and economic history of trafficking in human cells in her book, The Immortal Life of Henrietta Lacks (2005). ${ }^{55}$ Feminist scholars who are productively researching and hotly debating intersections between patriarchal systems of sexuality, militarism, and coercive trade and labor practices include Laura Agustin, Karen Bravo, Jo Doezema, Barbara Ehrenreich, Cynthia Enloe, Kathryn Farr, Kemala Kempadoo, and Julia O’Connell Davidson, to cite just a few.

Many governmental organizations and NGOs also are doing extraordinary work to create genuine social change. In 1995 the United Nations Fourth World Conference on Women, held in Beijing, China, developed a Platform for Action that, if heeded, would move the world a long way toward eliminating slavery and, more importantly, the desperate poverty that dooms countless people to misery. Many of the points articulated in Beijing bear repeating; we will cite just three crucial observations.

* More than 1 billion people in the world today, the great majority of whom are women, live in unacceptable conditions of poverty, mostly in the developing countries. Poverty is a complex, multidimensional problem, with origins in both the national and international domains.

* Women's poverty is directly related to the absence of economic opportunities and autonomy, lack of access to economic resources, including credit, land ownership and inheritance, lack of access to education and support services and their minimal participation in the decision-making process. Poverty can also force women into situations in which they are vulnerable to sexual exploitation.

* Sustainable development and economic growth that is both sustained and sustainable are possible only through improving the economic, social, political, legal and cultural status of women. Equitable social development that recognizes empowering the poor, particularly women, to utilize environmental resources sustainably is a necessary foundation for sustainable development. 56

In sum, current English and American popular political discourse usually represents the struggle for human liberation as a simple fable, Slavery vs. Freedom, that exudes a moral clarity. Reductive and illusory, this very clarity mitigates against the genuine social change envisioned in the Platform of Action cited 
above. Through its emotional appeal, the fable elaborates insidious justifications for sovereignal power: the right of the powerful to define which forms of labor exploitation, gender violence, and border crossings are legitimate and which are illegitimate. Those who invest in the fable are offered a heroic self-image because, as Toni Morrison observes, "Freedom (to move, to earn, to learn, to be allied with a powerful center, to narrate the world) can be relished more deeply in a cheek-by-jowl existence with the bound and unfree, the economically oppressed, the marginalized, the silenced." 57 When it reduces complex issues to a hackneyed plot, anti-human trafficking discourse offers its audience the illusion of "a safe route into meditations on morality and ethics; . . . a way of thinking about justice; a way of contemplating the modern world" in which it is the manifest destiny of the West to invade and save the rest. ${ }^{58}$ The quest for liberation is an on-going social process that involves disentangling our imaginations as well as our legal, economic, sexual and political institutions from the power of the powerful to construct "the" human story.

\section{NOTES}

Acknowledgments

The authors would like to thank the Humanities Institute at the University at Buffalo, which supported our work through funding faculty research fellowships, a conference on human trafficking, and a variety of topical lectures and workshops. We also are indebted to faculty conversations sponsored by UB's Gender Institute and the Baldy Center for Law and Social Policy. We are grateful to William L. Andrews, Karen Bravo, Steve Buckridge, Tim Dean, David Foster, Donald Grinde, Laura Hebert, Dominick LaCapra, Julia O'Connell Davidson, Dylan Rodriguez, Terry Rowden, Laurie Anne Whitt, Ewa Plonowska Ziarek and anonymous reviewers for helpful conversations and/or comments on this work.

1See Mike M. Ahlers, "Dramatic TV Ads Sell Anti-Human-Trafficking Message: 'Don't Be Fooled” (CNN 20 July 2011), http://edition.cnn.com/2011/WORLD/americas/07/19

/us.human.trafficking.campaign/

2Although few people will defend slavery publicly in the twenty-first century, on 13 January 2010 wealthy televangelist Pat Robertson blamed the devastating earthquake in Haiti on black revolutionaries who made "a pact with the devil" to overthrow slavery. "They were under the heel of the French," he said, "and they got together and made a pact to the devil. They said, "We will serve you if you'll get us free from the French.' True story," he continued. "And the devil said, 'OK, it's a deal. " Ever since, they have been cursed by one thing after another."

After a short media firestorm, Robertson's 700 Club issued a statement asserting that Robertson was citing "the widely discussed 1791 slave rebellion . . . where the slaves allegedly made a famous pact with the devil in exchange for victory over the French. This history, combined with the horrible state 
of the country, has led countless scholars and religious figures to believe the country is cursed." "Robertson blames quake on a 'pact with the devil,"' Buffalo News (14 January 2010), A2. 3 Michel-Rolph Trouillot, Silencing the Past: Power and the Production of History (Boston: Beacon Press, 1995), 28.

4 David Batstone, Not for Sale: The Return of the Global Slave Trade - and How We Can Fight It (New York: HarperCollins, 2007), 3.

5Ibid, 3 .

6Ibid, 4.

7See Christopher Lee Brown, Moral Capital: Foundations of British Abolitionism (Chapel Hill: University of North Carolina Press, 2006).

8Batstone, Not for Sale,12-13.

9Ibid, 17.

10 Ibid, 17.

11See Anibal Quijano, “Coloniality of Power: Eurocentrism and Latin America," in Nepantla: Views from South 1.3 (2000), 533-80; Edward Said, Orientalism (New York: Vintage, 1979); Walter Mignolo, Global History/Local Designs: Coloniality, Subaltern Knowledges, and Border Tbinking (Princeton: Princeton University Press, 2000).

12Nicholas D. Kristof and Sheryl WuDunn, Half the Sky: Turning Oppression into Opportunity for Women Worldwide (New York: Alfred A. Knopf, 2009), 24-25.

13 Batstone, Not for Sale, 12.

14Gary Haugen, Terrify No More: Young Girls Held Captive and the Daring Undercover Operation to Win Their Freedom (Nashville: Thomas Nelson Publishers, 2005).

15Noy Thrupkaew, “The Crusade Against Sex Trafficking: Do Brothel Raids Help or Hurt the 'Rescued'?,' The Nation (5 October 2009): 11-20.

16Kristof and WuDunn, Half the Sky, 57.

17Thrupkaew, "Crusade," 13.

18Nicholas D. Kristof, "How Can We Help?," New York Times Book Review (22 November 2009): 27. 19Nicholas D. Kristof, “Striking the Brothels' Bottom Line," New York Times Sunday Opinion (11 January 2009): WK12

20 Ibid.

$21 \mathrm{Karlan}$ and Krueger observe, “UNICEF makes two claims, that purchasing slaves' freedom for money (1) exacerbates the slave trade, and (2) does not address the root of the problem. Human Rights Watch (2002) also has denounced slave redemptions in the Sudan, citing concerns that monetary incentives could lead to more raiding of free Dinksa . . [and] that some of those who have been redeemed were not actually slaves." Dean S. Karlan and Alan B. Krueger, "Some Simple Analytics of Slave Redemption," in Buying Freedom: The Ethics and Economies of Slave Redemption, Kwame Anthony Appiah and Martin Bunzl, eds (Princeton: Princeton University Press, 2007, 9-19), 9.

22Batstone, Not for Sale, 61.

23Ibid, 62.

24Kristof and WuDunn, Half the Sky, 24. 
25 Ibid, 39.

26Julia O’Connell Davidson, "Men, Middlemen, and Migrants: The Demand Side of 'Sex

Trafficking,"' Eurozine (27 July 2006), http://www.eurozine.com/articles/2006-07-27-davidsonen.html.

27Tzvetan Todorov, Mikhail Babktin: The Dialogical Principle (Minneapolis: University of Minnesota Press, 1984), 96.

28Orlando Patterson, Freedom, Vol. 1: Freedom in the Making of Western Culture (New York: Basic Books, 1991), 51.

29 Ibid, 3 .

30Ibid, 3-4.

31 Ibid, 4.

32Anthony M. DeStefano, The War on Human Trafficking: U.S. Policy Assessed (New York: Rutgers University Press, 2008).

33Kristof and WuDunn, Half the Sky, 73.

34James R. Kincaid, Erotic Innocence: The Culture of Child Molesting (Durham, NC: Duke University Press, 1998), 30.

35Julia O'Connell Davidson, Children in the Global Sex Trade (Cambridge: Polity Press, 2005), 6.

36Kristof, "How," 27.

37Kevin Bales, Disposable People: New Slavery in the Global Economy, Revised Edition (Berkeley:

University of California Press, 2004), 4-5.

38Meredeth Turshen, "Review of Kevin Bales", Disposable People: New Slavery in the Global Economy, Journal of Public Health Policy 22.1 (2001), 119.

39Marcus Woods, Blind Memory: Visual Representations of Slavery in England and America, 1780-1865

(New York: Routledge, 2000), 44.

40Saidiya V. Hartman, Scenes of Subjection: Terror, Slavery, and Self-Making in Nineteenth-Century America (New York: Oxford University Press, 1997), 20-21.

41Julia O'Connell Davidson, Prostitution, Power and Freedom (Ann Arbor: University of Michigan Press,1998), 160.

42Gay W. Seidman, "Review of Kevin Bales", Disposable People: New Slavery in the Global Economy, Contemporary Sociology 25.2 (2001), 355.

43Turshen, 118.

44Ibid, 119.

45Kevin Bales, Ending Slavery: How We Free Today's Slaves (Berkeley: University of California Press, 2007), 100.

46Ibid, 102.

47 Ibid, 103.

48 Ibid, 105.

49 Ibid, 105.

50 Ibid, 107.

51 Kristof and WuDunn, Half the Sky, 99.

52Ishmael Beah, A Long Way Gone: Memoirs of a Boy Soldier (New York: Farrar, Straus, and Giroux, 
Quark 15.2draft FINISHED.qxd 11/21/11 2:占? PM Page 82

82

Winter and Castillo

2007).

53Dominick LaCapra, History and Its Limits: Human, Animal, Violence (Ithaca: Cornell University Press, 2009).

54 Michele Goodwin, Black Markets: The Supply and Demand of Body Parts (London: Cambridge University Press, 2006).

55 Rebecca Skloot, The Immortal Life of Henrietta Lacks (New York: Random House, 2011).

56 For the complete Platform for Action, see http://www.un.org/esa/gopher-

data/conf/fwcw/off/a-20.en.

57Toni Morrison, Playing in the Dark: Whiteness and the Literary Imagination (New York: Vintage, 1992),

64.

58Ibid, 64.
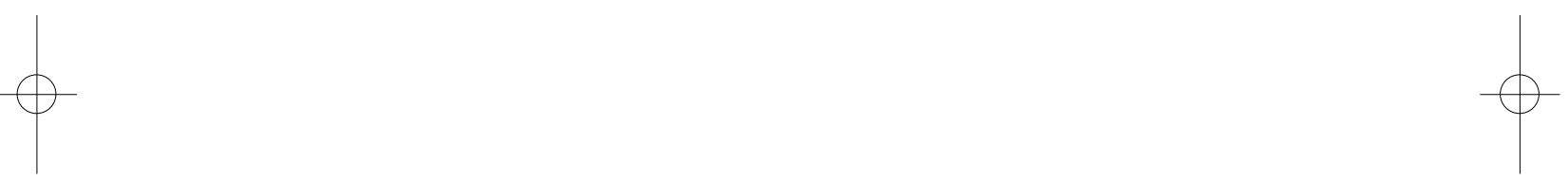